Danijela Rabar*

Andrej Grbin **
JEL Classification C44, C67, E62, R58

Prethodno priopćenje

https://doi.org/10.32910/ep.70.4.3

\title{
ANALIZA REGIONALNE EFIKASNOSTI U HRVATSKOJ KORIŠTENJEM FISKALNIH POKAZATELJA - NEPARAMETARSKI PRISTUP
}

Neravnomjeran gospodarski rast hrvatskih županija ukazuje na potrebu analize njihove usporedne (relativne) efikasnosti. Pritom bi, između ostaloga, istraživanje bilo zanimljivo usmjeriti na pokazatelje pod dominantnim utjecajem fiskalne politike. Upravo je to tema ovoga rada, a istraživanjem je obuhvaćeno razdoblje od 2002. do 2015. godine i uključeno šest pokazatelja u većem ili manjem opsegu povezanih s mjerama fiskalne politike. Dinamička je analiza provedena empirijski, korištenjem neparametarske metode analize omeđivanja podataka (AOMP), $i$ to na županijskoj razini na kojoj su dane $i$ smjernice za potrebna poboljšanja, što predstavlja novinu u odnosu na dosadašnje radove. Dobiveni rezultati efikasnosti 21 županije potvrdili su postavljene hipoteze o značajnim međužupanijskim nejednakostima $i$ vodećoj poziciji Grada Zagreba u svjetlu odabranih pokazatelja, ukazujući ujedno na generatore neefikasnosti, među kojima je najizraženiji broj zaposlenih u jedinicama lokalnih i područnih samouprava. Rezultati bi trebali poslužiti kreatorima ekonomske politike u nastojanjima unapređenja fiskalnih odluka s ciljem smanjenja regionalnih razlika.

Ključne riječi: fiskalni pokazatelji, gospodarski rast, (ne)efikasnost, hrvatske županije, analiza omeđivanja podataka, analiza prozora

* D. Rabar, docentica, Sveučilište Jurja Dobrile u Puli, Fakultet ekonomije i turizma (e-mail: drabar@unipu.hr)

** A. Grbin, student Sveučilište Jurja Dobrile u Puli, Fakultet ekonomije i turizma (e-mail: agrbin@unipu.hr)

Rad je primljen u uredništvo 09.07.2018. godine, a prihvaćen je za objavu 15.11.2018. godine. 


\section{Uvod}

Prisutnost značajnih odstupanja među regijama iste države, kao odraz njihova neujednačenog gospodarskog razvoja, opće je prihvaćena činjenica. To igra važnu ulogu u poticanju unutarnjih migracija iz manje razvijenih regija u razvijenije, što dovodi do daljnjeg produbljivanja spomenutih nejednakosti. Stoga vlade mnogih država pokušavaju uspostaviti politike u smjeru smanjenja regionalnih gospodarskih dispariteta. U tome nije iznimka ni Hrvatska, za koju se štoviše pokazalo da je recesija, koja je započela 2008. godine, imala značajan negativni utjecaj na disperziju indeksa razvijenosti, regionalnog BDP-a po stanovniku i regionalne produktivnosti (mjerene kao BDP po zaposleniku), odnosno da je zahvaljujući krizi došlo do daljnjeg povećanja ionako visoke razine regionalnih razlika (Đokić, Fröhlich i Rašić Bakarić, 2015). Budući da je poticanje razvoja slabije razvijenih regija, koje vodi k ujednačenijem regionalnom razvoju, tradicionalno jedan od ciljeva fiskalne politike, potrebno je što cjelovitije sagledati utjecaj fiskalnih pokazatelja na trend međužupanijskih nejednakosti kako bi se u cilju njihova smanjenja korigirale donesene mjere fiskalne politike. Nameće se zaključak o iznimnoj važnosti načina mjerenja stupnja regionalnog razvoja, koji uključuje odabir relevantnih pokazatelja i primjerene metodologije, kao temelja za određivanje društveno-ekonomskih politika zemlje.

Bruto domaći proizvod po stanovniku (BDP per capita) tradicionalno se smatra najboljom mjerom gospodarske aktivnosti, kako na nacionalnoj tako i na regionalnoj razini. Na osnovi toga pokazatelja mogu se utvrditi prostorni nerazmjeri životnog standarda i razlike u razvojnim mogućnostima pojedinih regija. U dinamičkim se analizama općenito preporučuje korištenje realnih vrijednosti BDP-a, kako bi se isključio utjecaj inflacije na njegove promjene i tako došlo do što realnije ocjene gospodarskog rasta i razvoja. No, dosadašnja su teorijska i empirijska istraživanja i rasprave velikog broja ekonomista pokazali kako, za stvaranje potpunije slike o stvarnom stupnju razvijenosti regija, nije dovoljno promatrati samo bruto domaći proizvod, već ga je nužno staviti u odnos s nizom drugih pokazatelja. ${ }^{1}$ Hoće li se u analizi uz BDP koristiti gospodarski, društveni i/ili demografski pokazatelji, ovisit će mahom o predmetu samog istraživanja. Što se tiče regionalnih nejednakosti, poznato je da na njih, između ostalih brojnih čimbenika, posredno ili neposredno utječu i mjere fiskalne politike koje se ogledaju kroz fiskalne pokazatelje. Cilj je ovoga istraživanja prikazati rezultate analize veličine utjecaja odabra-

1 U prilog tome govore zavaravajući rezultati koje u nekim slučajevima može dati korištenje isključivo podataka o BDP-u po stanovniku. Tako, primjerice, njegova visoka razina u određenom razdoblju ne mora biti rezultatom objektivne snage županijskog gospodarstva već prvenstveno značajnih investicija javnog sektora u infrastrukturu. 
nih pokazatelja dominantno fiskalnog karaktera i BDP-a na usporednu efikasnost hrvatskih županija, i to neparametarskom metodom analize omeđivanja podataka kao alternativom do sad korištenim pristupima u sličnim domaćim istraživanjima. Iz postavljenog cilja proizlaze i dvije hipoteze koje će se istraživanjem testirati. Prvom se hipotezom pretpostavlja postojanje značajnih regionalnih nejednakosti u Hrvatskoj pri čemu Grad Zagreb značajno pozitivno odstupa od ostalih županija. Drugom se hipotezom ukazuje na broj zaposlenih u jedinicama lokalne i područne samouprave kao na glavni izvor neefikasnosti.

Rad je podijeljen u pet poglavlja. Nakon uvoda, u drugome je dijelu dan kratak pregled dosadašnjih istraživanja koja povezuju fiskalnu politiku i regionalni razvoj. U trećemu dijelu slijedi opis odabranih pokazatelja i korištene metodologije za dizajn modela, dok je u četvrtome prikazana primjena modela u empirijskoj analizi i ocjena relativne efikasnosti županija. Rezultati istraživanja i njihove moguće implikacije za nositelje gospodarske politike, kao i zaključci o postavljenim hipotezama, sažeti su u posljednjem dijelu rada.

\section{Povezanost fiskalne politike i regionalnog razvoja kroz dosadašnja istraživanja}

Fiskalna politika, kao jedna od temeljnih poluga ekonomske politike, i njezin utjecaj na gospodarska kretanja, predmetom su brojnih istraživanja. No, bez obzira na koji se aspekt fiskalne politike usredotočili i na kojoj razini izučavali njegove učinke (državnoj, regionalnoj ili lokalnoj), i koje metode i modele koristili, od iznimnog je značaja empirijski pristup. Pregled empirijskih istraživanja o fiskalnoj politici u našoj zemlji daju Šimović, Ćorić i Deskar-Škrbić (2014), grupirajući ih prema području istraživanja (učinci fiskalne politike na ekonomski rast ili (pojedinu) ekonomsku aktivnost; utjecaj strukture javnih rashoda (i prihoda); karakter fiskalne politike; koordinacija monetarne i fiskalne politike (ili nekih elemenata fiskalne politike, npr. upravljanje javnim dugom); održivost fiskalne politike (i javnog duga); politička ekonomija i fiskalna politika). Međutim, uvrštena se istraživanja, kao i ona novijeg datuma (primjerice Šimović i Deskar-Škrbić, 2019), gotovo isključivo oslanjaju na statističke i ekonometrijske modele ${ }^{2}$, a fiskalne pokazatelje promatraju uglavnom na razini države, analizirajući pritom Hrvatsku kao jedini entitet ili ju uspoređujući s drugim zemljama (bilo tranzicijskim, bilo onima sred-

2 Iznimka su primjerice Bošnjak i Perić (2017) koji ekonometrijsku analizu (višestruku linearnu regresiju) kombiniraju s neekonometrijskim metodama (teorijom igara i PROMETHEE metodom), analizirajući međudjelovanje monetarne i fiskalne politike na primjeru Republike Hrvatske. 
nje i istočne Europe ili Europske unije). Čak se i u malobrojnim radovima koji donose empirijska istraživanja provedena na ispoddržavnoj razini, primjerice na razini gradova (Mačkić, 2014) ili na razini županija (Jurlina Alibegović, 2013), analiza vrši tako da se zaključci donose uopćeno, a ne na razini pojedinog entiteta. Iako su relevantnost i primjenjivost takvih istraživanja neupitne, rezultati dobivaju na težini ako je provedena analiza usporedna, odnosno ako se, bez obzira na razinu entiteta koje promatramo, oni međusobno uspoređuju. Na temelju rezultata usporedbe svakome se analiziranom entitetu mogu pružiti smjernice za poboljšanje njegovih performansi u okvirima onih parametara na koje on u većoj ili manjoj mjeri može utjecati. Pritom je iznimno važno odabrati metodu koja to omogućuje. Jedna od takvih svakako je analiza omeđivanja podataka. Prema saznanju auto$\mathrm{ra}, \mathrm{u}$ trenutku provođenja ovoga istraživanja samo jedan dostupan objavljeni rad (Kordić, Mihelja Žaja i Gardijan, 2018) u domaćoj literaturi koristi spomenutu metodu u kontekstu vrednovanja fiskalne politike, ali opet na razini država, uspoređujući međusobno 28 zemalja Europske unije.

U inozemnoj je literaturi broj radova koji relativnu efikasnost temeljenu na fiskalnim pokazateljima izučavaju na ispoddržavnoj razini znatno veći, ali je kod značajne većine njih također prisutan spomenuti nedostatak prezentacije rezultata na razini pojedinog entiteta. Među njima nije zanemariv broj onih koji istraživanje temelje na analizi omeđivanja podataka (primjerice Nold Hughes i Edwards, 2000).

Na temelju ovoga kratkog pregleda srodne literature, može se zaključiti kako potpuno izostaju radovi koji zaključke o utjecaju fiskalnih pokazatelja na relativnu efikasnost i posljedične smjernice poboljšanja donose na razini hrvatskih županija, pa ovaj rad u tome smislu predstavlja novinu.

\section{Model za ocjenu efikasnosti - pokazatelji, podatci i metodologija}

Različit izbor ulaznih i izlaznih varijabli dovodi do različitih rezultata efikasnosti koji su dodatno pod utjecajem odabira modela. Stoga su izbor pokazatelja i dizajn modela podobnog za primjenu u analizi određenog procesa, osobito pretpostavke njegova usmjerenja i prinosa, među najznačajnijim i najosjetljivijim koracima u izgradnji odgovarajućeg modela AOMP za procjenu usporedne ili relativne uspješnosti županija. Pritom pozornost svakako treba obratiti i na to koji se podatci vode i jesu li oni dostupni. 
D. RABAR, A. GRBIN: Analiza regionalne efikasnosti u Hrvatskoj korištenjem fiskalnih pokazatelja ... EKONOMSKI PREGLED, 70 (4) 627-649 (2019)

\subsection{Pokazatelji}

Polarizacija razvijenosti hrvatskih županija, potvrđena brojnim studijama, uzrokovana je i produbljena čitavim nizom čimbenika zasnovanih na ljudskom kapitalu i prirodnim resursima. Sveprisutni je to podsjetnik na potrebu smanjivanja međužupanijskih disproporcija i ključnu ulogu koju u tome ima fiskalna politika. Taj bi se fenomen trebao rješavati utvrđivanjem odnosa ključnih fiskalnih i drugih povezanih pokazatelja s gospodarskim rastom.

Nakon razmatranja širokog spektra relevantnih pokazatelja i njihova rangiranja prema važnosti, za ovo je istraživanje odabrano njih šest. Uz BDP, to su porezni prihodi, tekući rashodi, kapitalni rashodi, broj zaposlenih u jedinicama lokalne i područne (regionalne) samouprave, te ukupan broj zaposlenih umanjen za zaposlene u tijelima lokalne i područne samouprave i kod korisnika proračuna. Zbog kratkoće, za posljednja će se dva pokazatelja u nastavku koristiti kratice LRZAP i UKZAP.

Razlozi odabira spomenutih pokazatelja su sljedeći. Dvije kategorije rashoda prema funkcijskoj klasifikaciji proračuna, uvrštene u model, jesu tekući rashodi, koji obuhvaćaju rashode za zaposlene, materijalne rashode i financijske rashode, te kapitalni rashodi koji predstavljaju rashode za dobra koja uglavnom imaju vijek trajanja dulji od jedne godine i mogu utjecati na prihode u budućem razdoblju. Podjela rashoda napravljena je na taj način u namjeri da se, s jedne strane, obuhvate svi troškovi koje generira lokalna i područna vlast kako bi obavljala poslove u svojoj nadležnosti unutar jedne godine, a s druge strane, pruži uvid u kojoj mjeri lokalne i područne vlasti doprinose kapitalnim investicijama koje su, uz radnu snagu, prema mnogim modelima endogenog rasta među najznačajnijima (Scott, 1991; De Long i Summers, 1991). Sukladno tomu, u model je uvrštena i radna snaga, mjerena ukupnim brojem zaposlenih, kao varijabla koja pozitivno utječe na ekonomski rast, ali umanjena za broj zaposlenih u tijelima lokalne i područne samouprave i kod korisnika proračuna, koji neposredno utječe na razinu tekućih rashoda odnosno čiji porast može doprinijeti fiskalnoj neefikasnosti (Franić, 2012). $\mathrm{S}$ obzirom na problem vodoravne fiskalne nejednakosti, porezni prihodi koji su osnovni izvor financiranja proračunskih rashoda, a rezultat fiskalne politike, u model su uvršteni kao mjera fiskalnog kapaciteta županija (Bajo i Bronić, 2007).

Valja napomenuti da razina utjecaja kojega jedinice lokalne i područne samouprave imaju na pojedine odabrane pokazatelje značajno varira, o čemu treba voditi računa prilikom izrade smjernica na temelju rezultata dobivenih empirijskom analizom ${ }^{3}$.

3 Problem ograničenog utjecaja županija na pojedinu varijablu moguće je riješiti označavanjem te varijable kao nekontrolabilne. U tom bi slučaju ona i dalje utjecala na rezultat efikasnosti, 
U namjeri da se analiza učini što pouzdanijom, potrebne su određene prilagodbe pokazatelja. Kako bi se u obzir isključivo uzelo povećanje proizvodnje i uklonio učinak povećanja cijena, BDP je uzet u stalnim cijenama iz 2015. godine. Zbog neutraliziranja značajnih razlika među županijama u apsolutnim razinama pokazatelja, u dijelu koji je rezultat velikih razlika u broju stanovnika te posljedično u broju zaposlenih, u vrijednosti BDP-a i u veličini proračuna, svi su pokazatelji stavljeni u odnos s brojem stanovnika. Takve modifikacije prilagođavaju podatke u cilju uvažavanja promjene cijena i veličine populacije tijekom promatranog razdoblja, čime se dolazi do relevantnijih međužupanijskih usporedbi i jednostavnijeg tumačenja rezultata. Tih šest prilagođenih varijabli integrirat će se u jedinstvenu mjeru izvedbe.

Za izgradnju modela primjerenog za praćenje dinamičkog odnosa između BDP-a, kao standardne mjere nacionalnog gospodarskog učinka, i odabranih pokazatelja, samo se BDP uzima kao output dok se ostalih pet pokazatelja uzimaju kao inputi.

\subsection{Prikupljanje podataka}

Priroda odabranih pokazatelja omogućava usporedbu na godišnjoj razini. Podatci o njima, kao i o pomoćnim varijablama ${ }^{4}$ potrebnima za njihov izračun, preuzeti su sa službenih stranica Državnog zavoda za statistiku ([DZS], 2017, 2018a, 2018b, 2018c) i Ministarstva financija Republike Hrvatske ([MFIN], 2018), i zatim izmijenjeni u skladu s gore navedenim zahtjevima. Nedostupnost podataka o nekima od pokazatelja za razdoblje prije 2002. i nakon 2015. godine uvjetovala je vremenski opseg modela, u koji su tako, u svrhu usporedbe županija, uvršteni upravo podatci za razdoblje 2002.-2015.

U tablici 1 prikazana su osnovna statistička obilježja za prilagođene podatke svake varijable uvrštene u analizu.

ali bi pri formiranju projekcija neefikasnih županija na efikasnu granicu ostala nepromijenjena. To bi, međutim, dovelo u pitanje relevantnost rezultata jer je, kako je već rečeno, utjecaj županija na tu varijablu ograničen, ali ne i nepostojeći.

${ }^{4}$ Riječ je o broju stanovnika i indeksu potrošačkih cijena kao varijablama na koje jedinice lokalne i područne samouprave ne mogu neposredno utjecati. 
D. RABAR, A. GRBIN: Analiza regionalne efikasnosti u Hrvatskoj korištenjem fiskalnih pokazatelja ... EKONOMSKI PREGLED, 70 (4) 627-649 (2019)

\section{Tablica 1 .}

STATISTIKA POKAZATELJA KORIŠTENIH U ANALIZI, 2002.-2015.

\begin{tabular}{|l|l|r|r|r|r|r|c|}
\hline \multicolumn{2}{|c|}{ V a r i j a b I a } & $\begin{array}{c}\text { Srednja } \\
\text { vrijednost }\end{array}$ & Medijan & $\begin{array}{c}\text { Standardna } \\
\text { devijacija }\end{array}$ & Minimum & Maksimum & $\begin{array}{c}\text { Koeficijent } \\
\text { varijacije }\end{array}$ \\
\hline \multirow{3}{*}{ Inputi } & Porezni prihodi & $2.380,87$ & $2.123,48$ & $1.153,43$ & 735,55 & $7.030,35$ & 48,45 \\
\cline { 2 - 8 } & Tekući rashodi & $2.323,80$ & $2.076,87$ & 885,43 & 838,66 & $5.033,79$ & 38,10 \\
\cline { 2 - 9 } & $\begin{array}{l}\text { Kapitalni } \\
\text { rashodi }\end{array}$ & $1.155,87$ & $1.032,67$ & 541,74 & 400,80 & $3.426,68$ & 46,87 \\
\cline { 2 - 9 } & LRZAP & 74,55 & 68,06 & 28,20 & 21,29 & 141,79 & 37,84 \\
\cline { 2 - 9 } & UKZAP & $2.854,69$ & $2.667,84$ & 630,89 & $1.872,76$ & $5.253,16$ & 22,10 \\
\hline Output & BDP & $67.673,03$ & $62.412,53$ & $22.024,10$ & 40.639 .80 & $157.265,40$ & 32,54 \\
\hline
\end{tabular}

Izvor: Izračun autora na temelju podataka DZS (2017, 2018a, 2018b, 2018c) i MFIN (2018)

Budući da se u cilju poboljšanja učinkovitosti proizvodnim faktorima smatraju oni podatci za koje je poželjno smanjenje a outputima oni za koje je poželjno povećanje, za porezne se prihode i $\mathrm{UKZAP}^{6}$ uzimaju recipročne vrijednosti. Time se istodobno zadržavaju odnosi među podatcima i omogućuje procjena relativne efikasnosti županije kroz fiskalnu prizmu s ciljem minimiziranja tekućih i kapitalnih rashoda i LRZAP-a, a maksimiziranja BDP-a, prihoda od poreza i UKZAP-a.

\subsection{Metodološki okvir}

AOMP je neparametarska tehnika mjerenja performansi, koja se uobičajeno koristi za procjenu relativne efikasnosti grupe entiteta/donositelja odluka $(D O)$. Stvarni podatci o korištenim višestrukim inputima i stvorenim višestrukim outputima promatranih entiteta ugrađuju se u linearni program koji predstavlja model

5 Porezni prihodi, tekući i kapitalni rashodi i BDP uzeti su po stanovniku, dok su obje varijable koje se odnose na broj zaposlenih uzete na 10.000 stanovnika. Zbog jednostavnosti, u daljnjem će tekstu biti korišteni nazivi iz tablice, bez naznake da se radi o per capita a ne o apsolutnim iznosima varijabli.

6 Upravo da bi se izbjegla situacija u kojoj je za jedan dio neke varijable poželjno smanjenje a za drugi dio povećanje, što bi onemogućilo njezino nedvosmisleno određenje kao inputa ili outputa te posredno i jednoznačnu interpretaciju rezultata, iz ukupnog je broja zaposlenih (za koji je poželjan rast) izdvojen broj zaposlenih u tijelima lokalne i područne samouprave i kod korisnika proračuna (koji je nepoželjan i upućuje na potrebu za strukturnim promjenama - Bajo, 2009). 
AOMP i osigurava jedinstveni indeks efikasnosti relativne izvedbe. Na temelju tih podataka oblikuje se (efikasna) granica koja se sastoji od $D O$ koji pokazuju najbolju praksu te se klasificiraju kao efikasni (tzv. benchmarks), i koja istodobno obavija sve ostale, neefikasne $D O$. Potom se efikasnima dodjeljuje ocjena 1 (ili $100 \%$ ), a neefikasnima ocjena strogo između 0 i 1 ovisno o njihovoj udaljenosti od ove empirijski konstruirane granice koja inpute obavija odozdo a outpute odozgo. Ta je neefikasnost rezultat korištenja prevelike količine inputa za danu razinu outputa i/ili ostvarivanja premale količine outputa za danu razinu inputa, a može se ukloniti dostizanjem modelom izračunate efikasne točke projekcije na efikasnu granicu. Budući da je empirijski generirana, ova se granica pojavljuje kao objektivno ostvarivi cilj svakog neefikasnog $D O$, a istodobno služi kao osnova za prepoznavanje izvora njegove neefikasnosti i njihovih iznosa, smjerova poboljšanja i $D O$ referentnih za izravnu usporedbu.

Zbog svojih jedinstvenih robusnih svojstava, AOMP se primjenjuje u čitavom spektru kako profitnih tako i neprofitnih područja, kako na razini organizacija tako i na razini država. Koncept AOMP temelji se na seminarskom radu M. J. Farrella (1957). Od svoga nastanka i predstavljanja od strane Charnesa, Coopera i Rhodesa (1978) pa do godine 2014., objavljeno je u bazi ISI Web of Science približno 6500 radova koji se ovom metodom bave na razini teorijskog i praktičnog interesa (Liu, Lu i Lu, 2016). Razvijen je respektabilan broj modela AOMP obilježenih prije svega pretpostavkom prinosa (konstantnog ili varijabilnog) i usmjerenjem modela (na minimizaciju inputa ili na maksimizaciju outputa) te posljedično vrstom efikasnosti koju izračunavaju. Postoje i brojna njihova proširenja od kojih se jedno (analiza prozora) koristi u ovome radu. Stoga se ovaj pristup dokazano smatra međunarodno i akademski prepoznatim alatom za potporu odlučivanju.

Odlučujući čimbenik u odabiru ove metode u odnosu na tradicionalne tehnike benchmarkinga jest njezina mogućnost dinamičkog mjerenja efikasnosti, s inputima i outputima izraženima u različitim i često nespojivim mjernim jedinicama, a bez potrebe prethodnog određivanja težina varijabli ili eksplicitnog poznavanja funkcionalne veze između inputa i outputa. Štoviše, težine određuje sam model, na način koji maksimizira ocjenu efikasnosti za svaki promatrani entitet, dokidajući tako subjektivnost u procjeni važnosti svake težine.

Prva zadaća s kojom se analitičar mora suočiti nakon odabira pokazatelja jest određivanje vrste prinosa u skladu s kojom se procjenjuje granica proizvodnosti. U tom su smislu dva osnovna modela, najčešće korištena u primjenama AOMP, CCR (Charnes i sur., 1978) i BCC (Banker, Charnes i Cooper, 1984), nazvani prema inicijalima svojih autora. Prvi model pretpostavlja da funkcija proizvodnje pokazuje konstantan prinos, dok je drugi model, s pretpostavkom varijabilnog prinosa, jedno od njegovih brojnih teorijskih proširenja. Specifične preliminarne studije o procesu kojega se želi analizirati i ispitivanja njegovih svojstava mogu pružiti prvu 
naznaku vrste prinosa. Unatoč tome, svojstva granice proizvodnosti se ponekad, kao u našoj primjeni, ne mogu sa sigurnošću utvrditi što otežava izbor tipa modela. U tim slučajevima može, naime, biti rizično osloniti se na samo jedan određeni model. Jedno od mogućih rješenja je isprobati modele pod svakom od dviju pretpostavki na prinos, usporediti njihove rezultate $i$, na temelju stupnja njihovih razlika i korištenjem stručnog znanja o problemu, pronaći najprikladniji tip pretpostavke za analizu. Tako provedena prva faza ovdje predstavljenoga istraživanja pokazala je da se rezultati dobiveni iz navedenih modela značajno razlikuju, što se može pripisati efektu prinosa s obzirom na raspon aktivnosti. To model BCC čini prikladnijim za opisivanje istraživanog procesa, pa je razlogom odabira toga modela za daljnju analizu.

Sljedeći je problem s kojim se analitičar mora suočiti odabir usmjerenja modela. Naime, ovisno o tome je li menadžerski izbor prije svega smanjenje ulaznih vrijednosti ili pak povećanje izlaznih veličina, modeli AOMP usmjereni su na inpute ili na outpute. Ova razlika u usmjerenju modela rezultira različitim smjerovima projekcije na efikasnu granicu te posljedično različitim točkama projekcije neefikasnih $D O$. Budući da se udaljenosti neefikasnog $D O$ i njegovih projekcija usmjerenih na inpute i na outpute očito razlikuju, efikasnost nije jednako ostvariva u različito usmjerenim modelima. Kako je ovdje BDP jedini output među šest odabranih pokazatelja, usmjerenje na inpute odabrano je kao prikladnije jer pruža mogućnost procjene mjere u kojoj bi se inputi trebali poboljšati, bez smanjenja ostvarenog iznosa outputa, kako bi se DO smatrao relativno efikasnim. Kratki opis modela u nastavku temelji se na Cooper, Seiford i Tone (2006, str. 87-89). Sukladno tome, radi se o ocjeni relativne efikasnosti $n D O\left(\mathrm{DO}_{j}, j=1,2, \ldots, n\right)$, od kojih svaki koristi $m$ inputa za stvaranje $s$ outputa. Model BCC usmjeren na inpute ocjenjuje efikasnost $D O_{0}$ rješavanjem sljedećeg linearnog programa:

$$
\begin{array}{ll} 
& \min _{\theta_{B}, \lambda} \theta_{B} \\
& \theta_{B} x_{o}-X \lambda \geq 0 \\
& Y \lambda \geq y_{o} \\
& e \lambda=1 \\
& \lambda \geq 0
\end{array}
$$

gdje je $X=\left(x_{j}\right) \in \mathbb{R}^{m \times n}$ matrica utrošenih inputa, a $Y=\left(x_{j}\right) \in \mathbb{R}^{s \times n}$ matrica ostvarenih outputa, $\lambda \in \mathbb{R}^{n}$, a $e n$-dimenzionalni vektor-redak čiji su svi elementi jednaki 1. Stoga se uvjeti (1), (2) i (4) sastoje od $m, s$ i $n$ ograničenja, respektivno. U slučaju kojega se ovdje analizira, $n$ je $21, m$ je 5 , a $s$ je 1 . Vektor $\lambda$ pokazuje mjeru 
u kojoj efikasni $D O$ doprinose projekciji neefikasnog $D O_{0}$ na efikasnu granicu. Optimalna vrijednost $\theta_{B}$ funkcije cilja predstavlja iznos efikasnosti za $D O_{0}$ a, ukoliko je on neefikasan, također i faktor smanjenja inputa $\left(0 \leq \theta_{B}^{*} \leq 1\right)$.

Ova prva faza minimizira $\theta_{B}$, a prva dva ograničenja pripadnog linearnog programa pokazuju da $(X \lambda, Y \lambda)$ nadmašuje $\left(\theta_{B}^{*} x_{o}, y_{o}\right)$ kada je $\theta_{B}^{*}<1$. U tom se kontekstu viškovi inputa i manjkovi outputa (tzv. dopunske varijable) računaju formulama

$$
s^{-}=\theta_{B} x_{o}-X \lambda, \quad s^{+}=Y \lambda-y_{o}
$$

gdje je $s^{-} \in \mathbb{R}^{m}, s^{-} \geq 0$ i $s^{+} \in \mathbb{R}^{s}, s^{+} \geq 0$ za svako moguće rješenje $\left(\theta_{B}, \lambda\right)$.

U drugoj će fazi eventualni preostali viškovi inputa i manjkovi outputa biti otkriveni maksimiziranjem njihova zbroja uz zadržavanje $\theta_{B}=\theta_{B}^{*}$.

Definicija 1 (BCC efikasnost):

Ako optimalno rjě̌enje $\left(\theta_{B}^{*}, \lambda^{*}, s^{-*}, s^{+*}\right)$ modela $B C C$ (dobiveno uz pomoć opisanoga dvofaznog postupka) zadovoljava $\theta_{B}^{*}=1$ i nema dopunskih varijabli $\left(s^{-*}=0, s^{+*}=0\right)$, tada se DO naziva BCC efikasnim, u suprotnom je BCC neefikasan.

Definicija 2 (referentni skup):

Za BCC neefikasni $D_{0} O_{0}$ definira se njegov referentni skup $E_{0}$ baziran na optimalnom rješenju $\lambda^{*} s$

$$
E_{o}=\left\{j \mid \lambda_{j}^{*}>0\right\} \quad(j \in\{1,2, \ldots, n\}) .
$$

Svako od eventualno višestrukih optimalnih rješenja izražava se kao:

$$
\begin{aligned}
& \theta_{B}^{*} x_{o}=\sum_{j \epsilon E_{o}} x_{j} \lambda_{j}^{*}+s^{-*}, \\
& y_{o}=\sum_{j \epsilon E_{o}} y_{j} \lambda_{j}^{*}-s^{+*} .
\end{aligned}
$$

Navedene relacije sugeriraju da se efikasnost od $\left(x_{0}, y_{0}\right)$ za $D O_{0}$ može doseći ako se vrijednosti inputa smanje proporcionalno s omjerom $\theta_{B}^{*} \mathrm{i}$ ako se uklone viškovi inputa zabilježeni u $s^{-*}$, a vrijednosti outputa povećaju manjkovima outputa u $s^{+^{*}}$. Opisano poboljšanje može se izraziti sljedećom formulom (tzv. BCC projekcija):

$$
\begin{aligned}
& \hat{x}_{o}=\theta_{B}^{*} x_{o}-s^{-*}, \\
& \hat{y}_{o}=y_{o}+s^{+*} .
\end{aligned}
$$


Budući da je razdoblje kojega će se analizirati podijeljeno na četrnaest podrazdoblja, potrebno je osigurati prikladan pregled dobivenih rezultata tijekom vremena. To će se omogućiti analizom prozora gdje svaki prozor, kao razdoblje unutar kojega se usporedbe provode, ovisno o svojoj duljini može obuhvaćati od jedne do četrnaest godina. Ovim se dinamičkim proširenjem osnovnog modela AOMP relativna efikasnost određene županije može procijeniti ne samo u odnosu na druge županije unutar istog podrazdoblja, već i u odnosu na rezultate drugih županija, uključujući i vlastite, iz drugih podrazdoblja. Međutim, ovisno o svrsi analize, potrebno je odrediti duljinu prozora iz koje se potom izvodi broj prozora. Kako bi se analiza učinila što uravnoteženijom, nužno je sve promatrane godine tretirati ravnopravno. To je moguće samo u slučajevima s minimalnom ili maksimalnom duljinom prozora. U prvome slučaju postoji četrnaest jednogodišnjih prozora, dok je u drugome samo jedan četrnaestogodišnji pri čemu se model konstruira kao i osnovni, s razlikom u broju promatranih entiteta. Kako bi se postigao cilj ovoga istraživanja i u isto vrijeme premostio spomenuti nedostatak, razmatrat će se upravo ova dva slučaja.?

\section{Primjena modela u empirijskoj analizi i ocjena relativne efikasnosti županija}

Rezultati relativne efikasnosti 21 hrvatske županije, prikazani u daljnjem tekstu, dobiveni su izračunom autora na temelju rezultata programa DEA-Solver-Pro, primijenjenog na modelu usmjerenom na inpute uz pretpostavku varijabilnog prinosa.

7 Ako bi se primjerice odabrala duljina prozora od deset godina, bilo bi pet prozora (20022011, 2003-2012, 2004-2013, 2005-2014 i 2006-2015), pa bi se rubne godine testirale samo u po jednom prozoru, početna u prvom a završna u zadnjem, dok bi se primjerice 2006. godina testirala u svim prozorima. 


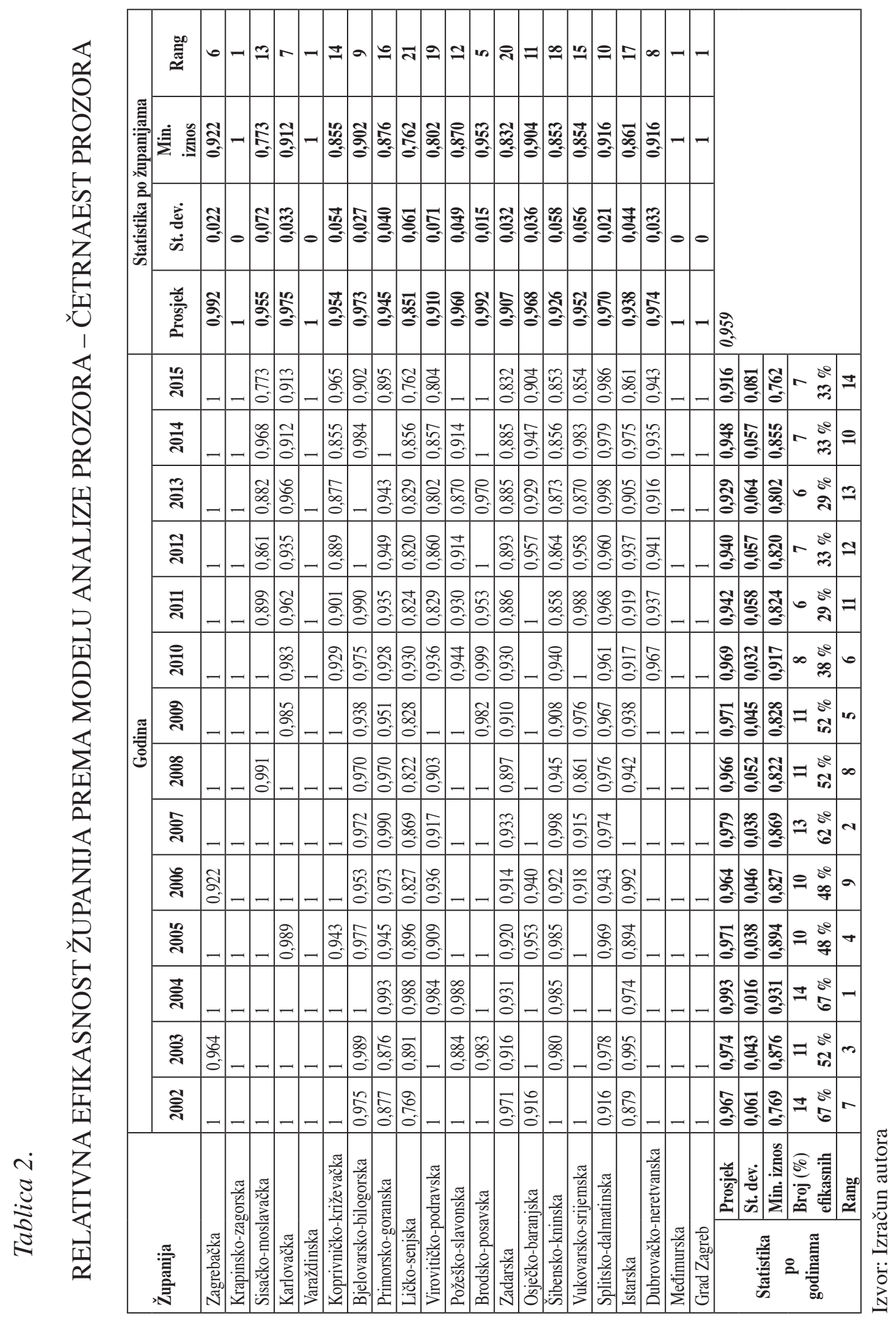


Prvi model koristi četrnaest jednogodišnjih prozora. Na taj se način izvedba svake županije u određenoj godini uspoređuje samo s izvedbama preostalih županija u toj istoj godini, što se promatra zasebno za svaku godinu. Budući da se svaka županija smatra pojedinačnim entitetom za svaku godinu, efikasnost se u ovome modelu analizira unutar četrnaest skupova od kojih se svaki sastoji od 21 entiteta. Iznosi relativne efikasnosti, prikazani u tablici 2, omogućuju usporedbu performansi svih županija u istoj godini kao i usporedbu iznosa efikasnosti jedne županije tijekom svih godina. Dana je i statistika efikasnosti po županijama i po godinama, kao i rang županija i godina prema prosječnim iznosima efikasnosti.

Najviši prosječni iznos efikasnosti na godišnjoj razini $(0,993)$ ostvaren je u 2004. godini, a najniži $(0,916)$ u 2015. Najviše je efikasnih županija (14) u 2002. i 2004., a najmanje (6) u 2011. i 2013. godini. Kontinuirano efikasne županije su Krapinsko-zagorska, Varaždinska, Međimurska i Grad Zagreb, dok su jedine neprekidno neefikasne Ličko-senjska i Zadarska pri čemu je zanimljivo napomenuti da je Zadarska najmanje efikasna u samo jednoj godini a Ličko-senjska u čak devet od četrnaest promatranih godina. Razlika između najvišeg i najnižeg ostvarenog iznosa efikasnosti $(0,227)$ najizraženija je kod Sisačko-moslavačke i Ličko-senjske županije koje su se obje najmanje efikasnima pokazale u posljednjoj analiziranoj godini. Niti jedna županija ne pokazuje kontinuirani pad ili kontinuirani rast relativne efikasnosti. Sveukupna prosječna ocjena efikasnosti od 0,959 ukazuje na to da su županije u prosjeku neefikasne svega $4,1 \%{ }^{8}$.

Standardna odstupanja očito su znatno manja kada se promatra ista županija $\mathrm{u}$ različitim godinama nego kada se promatraju različite županije u istoj godini. To ukazuje na relativno uravnotežene performanse tijekom vremena na razini županije, ali i na prisutne međužupanijske nejednakosti. Značajne razlike između minimalnih i maksimalnih rezultata efikasnosti u pojedinim slučajevima posebno potvrđuju te nejednakosti.

Uvažavajući činjenicu da nudi vrijedne informacije o trendovima relativne efikasnosti, značaj analize prozora u okviru AOMP izvan svake je sumnje. Modeli s prozorima, međutim, ne pružaju prijeko potrebne informacije o izvorima neefikasnosti i prijedlozima poboljšanja. Dobivanje tih informacija uključuje pokretanje osnovnog modela BCC četrnaest puta - po jednom za svaku pojedinu godinu. Razine efikasnosti u ovih četrnaest analiza identične su onima prikazanima tablicom 2. Viškovi inputa i manjkovi outputa, odnosno razlike između stvarnih i projiciranih vrijednosti, izračunate su u svakoj varijabli, uzimajući u obzir ranije spomenutu izvršenu prilagodbu izvornih podataka. Te su razlike zatim uprosječene po županijama i izražene u tablici 3 kao postotci odgovarajućih inicijalnih vrijednosti, a predstavljaju potrebna poboljšanja koja se mogu postići korištenjem

$8 \quad(1-0.959) * 100$ 
prethodno objašnjenog dvofaznog postupka ${ }^{9}$. U 2012. godini, primjerice, najizraženiji je višak od $17,38 \%$ u broju zaposlenih u jedinicama lokalne i područne samouprave, od čega $6 \%{ }^{10}$ otpada na radijalnu neefikasnost i uklanja se u prvoj fazi, a preostalih $11,38 \%$ do traženog iznosa na mješovitu neefikasnost koja se uklanja u drugoj fazi.

\section{Tablica 3 .}

\section{IZVORI RELATIVNE NEEFIKASNOSTI ŽUPANIJA I NJIHOVA VELIČINA} PREMA MODELU ANALIZE PROZORA - ČETRNAEST PROZORA

\begin{tabular}{|c|c|c|c|c|c|c|c|}
\hline \multirow{4}{*}{} & \multirow{7}{*}{ Godina } & \multicolumn{7}{|c|}{ Inputi } \\
\cline { 3 - 8 } & & $\begin{array}{c}\text { Porezni } \\
\text { prihodi }\end{array}$ & $\begin{array}{c}\text { Tekući } \\
\text { rashodi }\end{array}$ & $\begin{array}{c}\text { Kapitalni } \\
\text { rashodi }\end{array}$ & LRZAP & UKZAP & BDP \\
\cline { 2 - 8 } & $\mathbf{2 0 0 2}$ & 6,03 & $-4,62$ & $-4,69$ & $-6,49$ & 4,22 & 4,49 \\
\cline { 2 - 8 } & $\mathbf{2 0 0 3}$ & 6,47 & $-3,96$ & $-4,37$ & $-10,70$ & 11,81 & 7,20 \\
\cline { 2 - 8 } & $\mathbf{2 0 0 4}$ & 3,39 & $-2,11$ & $-4,50$ & $-4,69$ & 4,92 & 0,95 \\
\cline { 2 - 8 } & $\mathbf{2 0 0 5}$ & 3,45 & $-3,73$ & $-5,92$ & $-8,36$ & 4,37 & 5,55 \\
\cline { 2 - 8 } & $\mathbf{2 0 0 6}$ & 4,36 & $-5,25$ & $-10,63$ & $-9,38$ & 5,96 & 2,96 \\
\cline { 2 - 8 } $\begin{array}{c}\text { inputa } \\
\text { outputa } \\
(\mathbf{\%})\end{array}$ & $\mathbf{2 0 0 7}$ & 2,25 & $-2,62$ & $-4,85$ & $-5,80$ & 2,71 & 2,79 \\
\cline { 2 - 8 } & $\mathbf{2 0 0 8}$ & 3,89 & $-4,18$ & $-6,34$ & $-8,03$ & 4,53 & 3,88 \\
\cline { 2 - 8 } & $\mathbf{2 0 0 9}$ & 3,34 & $-3,11$ & $-4,35$ & $-5,44$ & 4,89 & 6,86 \\
\cline { 2 - 8 } & $\mathbf{2 0 1 0}$ & 5,66 & $-3,39$ & $-10,78$ & $-11,88$ & 4,92 & 7,08 \\
\cline { 2 - 8 } & $\mathbf{2 0 1 1}$ & 13,17 & $-6,06$ & $-12,80$ & $-18,24$ & 11,30 & 11,24 \\
\cline { 2 - 8 } & $\mathbf{2 0 1 2}$ & 7,42 & $-6,28$ & $-11,87$ & $-17,38$ & 7,41 & 9,13 \\
\cline { 2 - 8 } & $\mathbf{2 0 1 3}$ & 9,27 & $-8,47$ & $-17,78$ & $-21,12$ & 14,15 & 14,49 \\
\cline { 2 - 8 } & $\mathbf{2 0 1 4}$ & 7,00 & $-6,92$ & $-11,60$ & $-19,73$ & 7,47 & 9,77 \\
\cline { 2 - 8 } & $\mathbf{2 0 1 5}$ & 16,61 & $-8,35$ & $-20,14$ & $-22,38$ & 10,31 & 13,83 \\
\hline
\end{tabular}

Izvor: Izračun autora

9 Budući da model za inpute uvijek zahtijeva smanjenja, valja posebnu pozornost obratiti na porezne prihode i UKZAP. Naime, kako je ranije pojašnjeno, za ta su dva inputa uzete recipročne vrijednosti, pa za njih traženo smanjenje od primjerice $20 \%$ zapravo znači traženo povećanje od $25 \%$. Konkretno, smanjenje recipročne vrijednosti $\frac{1}{X}$ na $0,8 \cdot \frac{1}{X}$ ekvivalentno je povećanju vrijednosti $X$ na $\frac{1}{0,8 \cdot \frac{1}{X}}=1,25 \cdot X$.

10 Prosječna efikasnost u 2012. godini iznosi 0,940 (tablica 2). 
Razumljivo je da su značajne prosječne zahtijevane promjene količina inputa i outputa posljedica velikih traženih poboljšanja neefikasnih županija, što pak ukazuje na međužupanijsku divergenciju. U čak deset od četrnaest promatranih godina, najveći utjecaj na efikasnost, u smislu spomenutih zahtijevanih poboljšanja, ima broj zaposlenih u jedinicama lokalne i područne samouprave. Taj je utjecaj osobito izražen u posljednje četiri analizirane godine, s tendencijom daljnjeg povećanja. Jedna od iznimki je primjerice 2009. godina, u kojoj vodeći utjecaj na efikasnost preuzima BDP. Razlog tome nesumnjivo je u činjenici da se, slijedom recesijskih kretanja, upravo u toj godini dogodio njegov najveći pad. S druge strane, tekući su rashodi najslabijim uzrokom neefikasnosti u osam slučajeva, od čega je sedam posljednjih godina promatranoga razdoblja. Zanimljivost je da su svi pokazatelji u svim godinama u manjoj ili većoj mjeri uzrokovali neefikasnost, što na određeni način svjedoči o relevantnosti njihova odabira za ovo istraživanje.

Budući da se u ovome modelu svaka godina razmatra zasebno, najbolji rezultat efikasnosti određene županije u nekoj godini ne ukazuje nužno na njezine najbolje performanse u odnosu na ostale godine promatranog razdoblja. To samo znači da su njezine performanse u usporedbi s drugim županijama u toj godini bile bolje od njezinih performansi u usporedbi s drugim županijama u ostalim godinama. Stoga ovaj model nije pogodan za izravne usporedbe kroz godine za svaku županiju, budući da je baza za uspoređivanje različita za svaku godinu. Slijedom toga, čini se smislenim proširiti usporedbu kako bi se u nju istodobno uključile performanse svih županija u svim godinama. U takvome će se modelu procjena relativne efikasnosti temeljiti na istih šest pokazatelja, no sada uz korištenje jednoga četrnaestogodišnjeg prozora. Na taj se način performanse svake županije u svakoj godini uspoređuju s performansama svih županija u svim godinama, uključujući i nju samu. Efikasnost se u ovome modelu stoga analizira unutar jednog skupa sa 294 (= 14 x 21) entiteta, što čini ključnu razliku između ovog i prethodnog modela. Rezultati relativne efikasnosti prema novome modelu prikazani su u tablici 4, zajedno s elementima deskriptivne statistike koji pojednostavljuju usporedbu s rezultatima prethodnoga modela iz tablice 2 . 


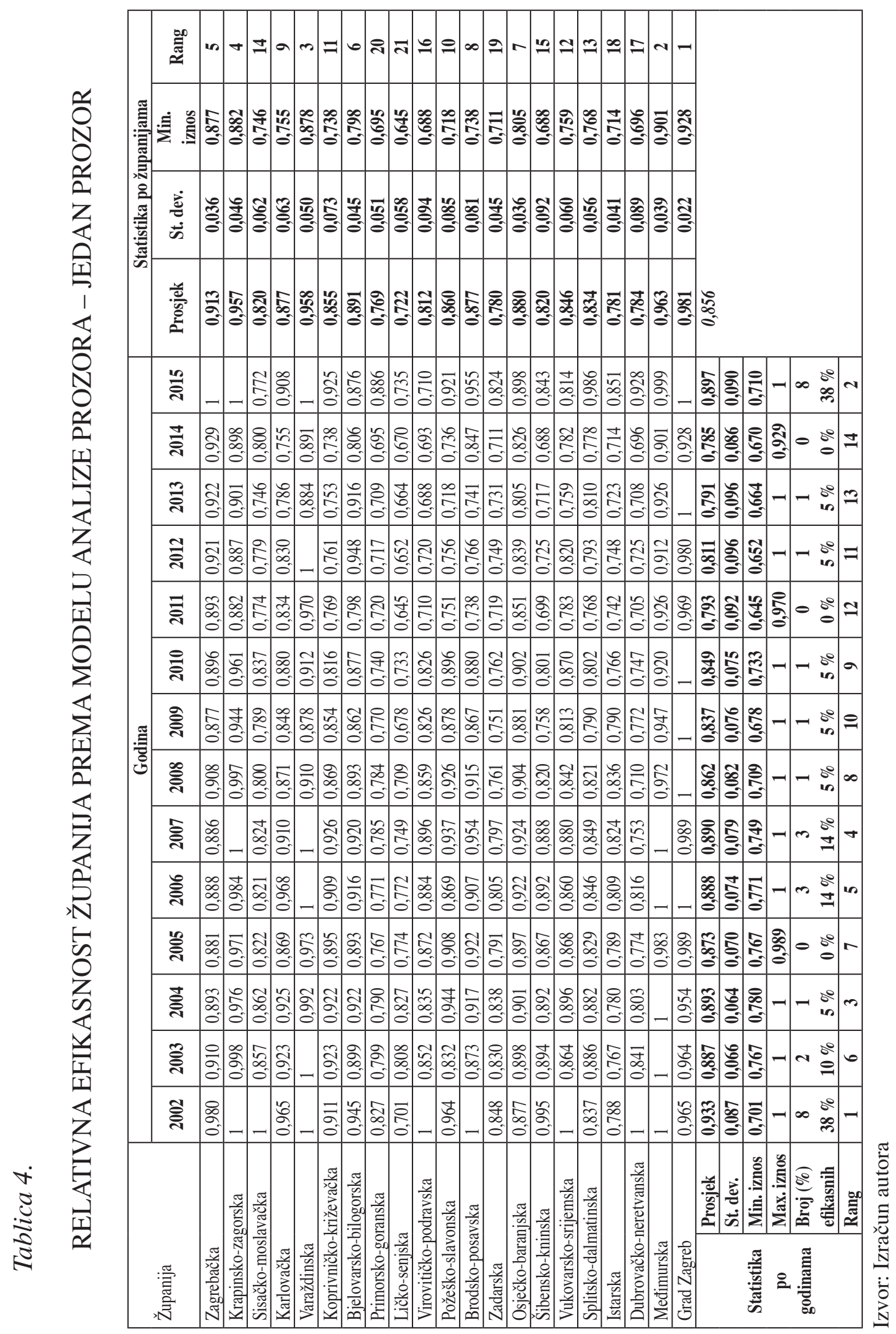


Očigledno je da niti jedna županija nije uspjela ostvariti kontinuiranu efikasnost. Od 294 promatrana entiteta, samo je 26 relativno efikasnih. Grad Zagreb i Varaždinska županija efikasni su u šest, Međimurska u pet i Krapinsko-zagorska u tri godine. Šest županija efikasnost je dostiglo u samo jednoj godini, dok je preostalih 11 kontinuirano neefikasno. Niti jedna županija nije postigla neprekinuti rast ili neprekinuti pad efikasnosti. Godina 2002. daleko je najuspješnija, kako po broju efikasnih županija (8) tako i po prosječnom iznosu efikasnosti $(0,933)$. Najmanje uspješna je 2014., s prosječnim iznosom efikasnosti 0,785 i bez ijedne efikasne županije. Efikasnih županija nije bilo ni u 2005. i 2011. godini. Treba naglasiti da niti jedan iznos efikasnosti u novome modelu nije veći od odgovarajućeg iznosa u prethodnome, što se može pripisati duljini prozora odnosno obuhvatu podataka za pojedinu usporedbu. Naime, za pojedini je entitet povoljnija usporedba sa 20 entiteta (prvi model) nego sa 293 entiteta (drugi model) među kojima je i spomenutih 20.

Najmanji od 294 iznosa efikasnosti $(0,645)$ ostvarila je Ličko-senjska županija u 2011. godini. Slično prethodnome modelu, ta je županija zabilježila i najnižu prosječnu ocjenu efikasnosti $(0,722)$, dok je najvišu $(0,981)$ ostvario Grad Zagreb. Ovi brojevi svjedoče opet o razlikama među hrvatskim županijama, koje su u ovome modelu još izraženije nego u prethodnome. Najznačajniji skok efikasnosti u odnosu na prethodnu godinu, kako negativan (-0,159 u 2003.) tako i pozitivan $(+0,232 \mathrm{sa} \mathrm{u}$ 2015.), ostvarila je ista, Dubrovačko-neretvanska županija. Ta je županija zanimljiva i zbog najvećeg pada prosječnog iznosa efikasnosti u drugome modelu, u kojemu je efikasnost ostvarila samo u prvoj godini, u odnosu na prvi model u kojemu je bila efikasna u čak osam (prvih) uzastopnih godina, što je ujedno rezultiralo najvećim pogoršanjem ranga (za devet mjesta). To se može predočiti sljedećim primjerom. Ako se performanse Dubrovačko-neretvanske županije iz 2008. godine usporede samo s performansama ostalih županija u istoj godini (prvi model), niti jedna županija ne pokazuje se efikasnijom od nje. Ako se pak njezine performanse iz iste godine usporede s performansama svih županija, uključivši i nju samu, u svim godinama promatranoga razdoblja, čak 276 od 294 entiteta pokazuje veću efikasnost od nje, uključujući i nju samu s performansama iz ostalih godina (osim 2011., 2013. i 2014.).

Očekivano, može se ustvrditi da među rezultatima dvaju modela postoje određene sličnosti, ali i izrazite razlike. Devet je županija koje su bolje rangirane u prvome, a deset onih koje su bolje rangirane u drugome modelu. Jedine dvije županije koje su zadržale rang ujedno su najbolje (Grad Zagreb) i najlošije (Ličkosenjska) rangirane. Prosječna ocjena efikasnosti (za sve županije u cijelom razdoblju) od 0,856 ukazuje na to da su županije u prosjeku neefikasne $14,4 \%$, što je znatno više nego u prethodnome modelu. Posljedica je to činjenice da su prosječne iznose efikasnosti u drugome modelu, u odnosu na prvi, pogoršale sve županije, ali je ta promjena kod nekih više a kod nekih manje izražena, o čemu svjedoče spomenute promjene $u$ rangu. 
Izvori neefikasnosti u obliku traženih poboljšanja inputa i outputa, uprosječenih kroz promatrano razdoblje, dani su u tablici 5.

Situacija s obzirom na utjecaj pokazatelja na razine efikasnosti u ovome je modelu znatno jasnija nego u prethodnome. Tako broj zaposlenih u jedinicama lokalne i područne samouprave ponovno ima najveći utjecaj na neefikasnost, ali ovoga puta uz samo dvije iznimke (u 2009. i 2010. godini, kada to ima BDP) i znatno jače nego u prethodnome modelu. Na efikasnost ponovno najmanji utjecaj imaju tekući rashodi, ali sada sa samo jednom iznimkom (u posljednjoj godini, kada to ima BDP). Očigledno je BDP jedini pokazatelj koji se istodobno nalazi i među pokazateljima s najslabijim i među pokazateljima s najjačim utjecajem na efikasnost. Zašto je BDP u 2009. godini preuzeo vodeći utjecaj na efikasnost pojašnjeno je kod prethodnoga modela, dok se njegov najmanji utjecaj na efikasnost u 2015. može jednostavno obrazložiti činjenicom da je ta godina prva godina njegova rasta nakon šest uzastopnih godina recesije. Činjenica da su, u odnosu na prethodni model, razlike između hrvatskih županija dublje opet je izravna posljedica razlike u duljini prozora.

\section{Tablica 5.}

\section{IZVORI RELATIVNE NEEFIKASNOSTI ŽUPANIJA I NJIHOVA VELIČINA PREMA MODELU ANALIZE PROZORA - JEDAN PROZOR}

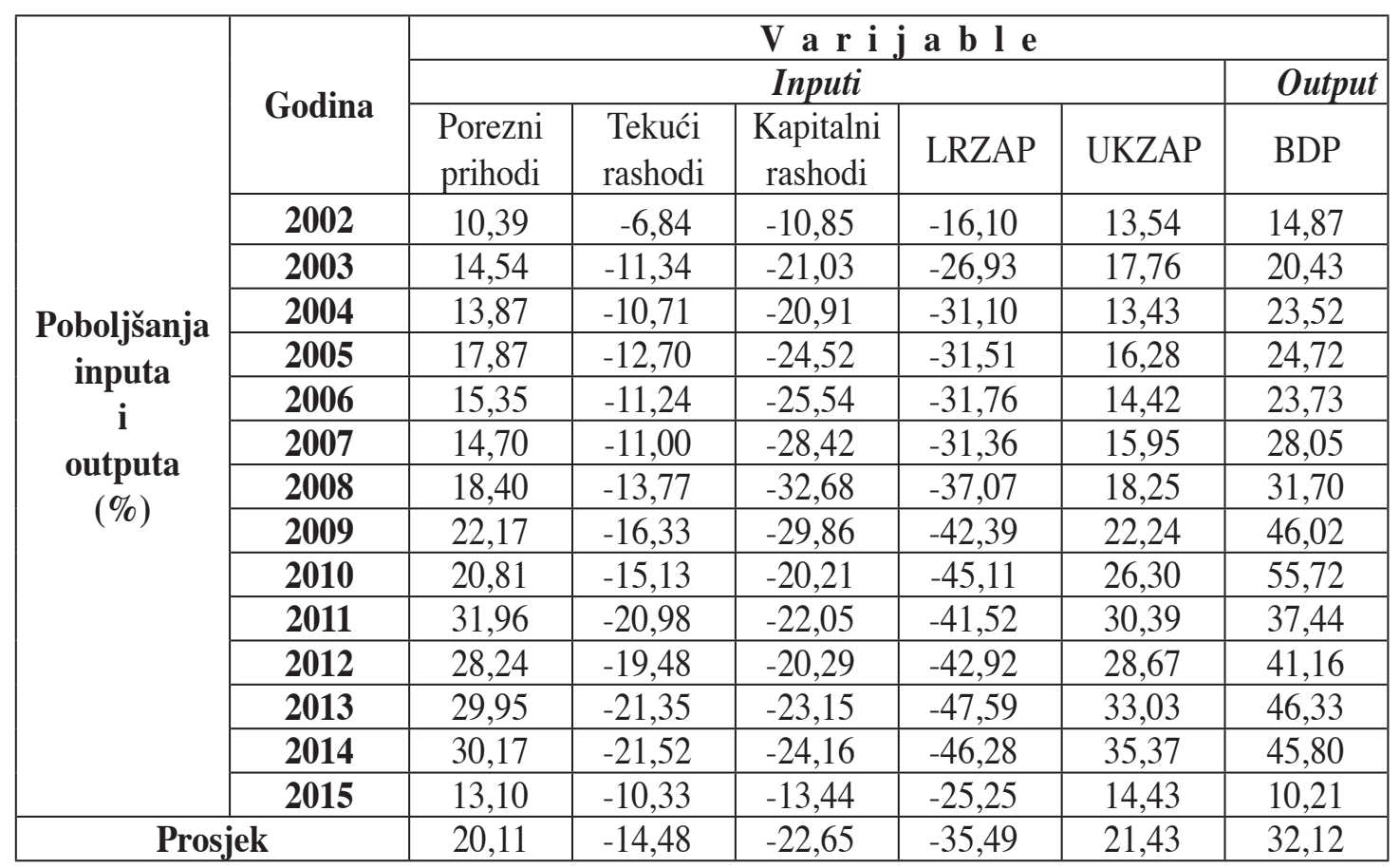

Izvor: Izračun autora 
Stavljajući u odnos doprinose pokazatelja neefikasnosti (slika), očigledan je najveći udio broja zaposlenih u jedinicama lokalne i područne samouprave $(24 \%)$ i najmanji udio tekućih rashoda $(10 \%)$.

Slika.

DOPRINOS INPUTA I OUTPUTA NEEFIKASNOSTI PREMA MODELU ANALIZE PROZORA - JEDAN PROZOR

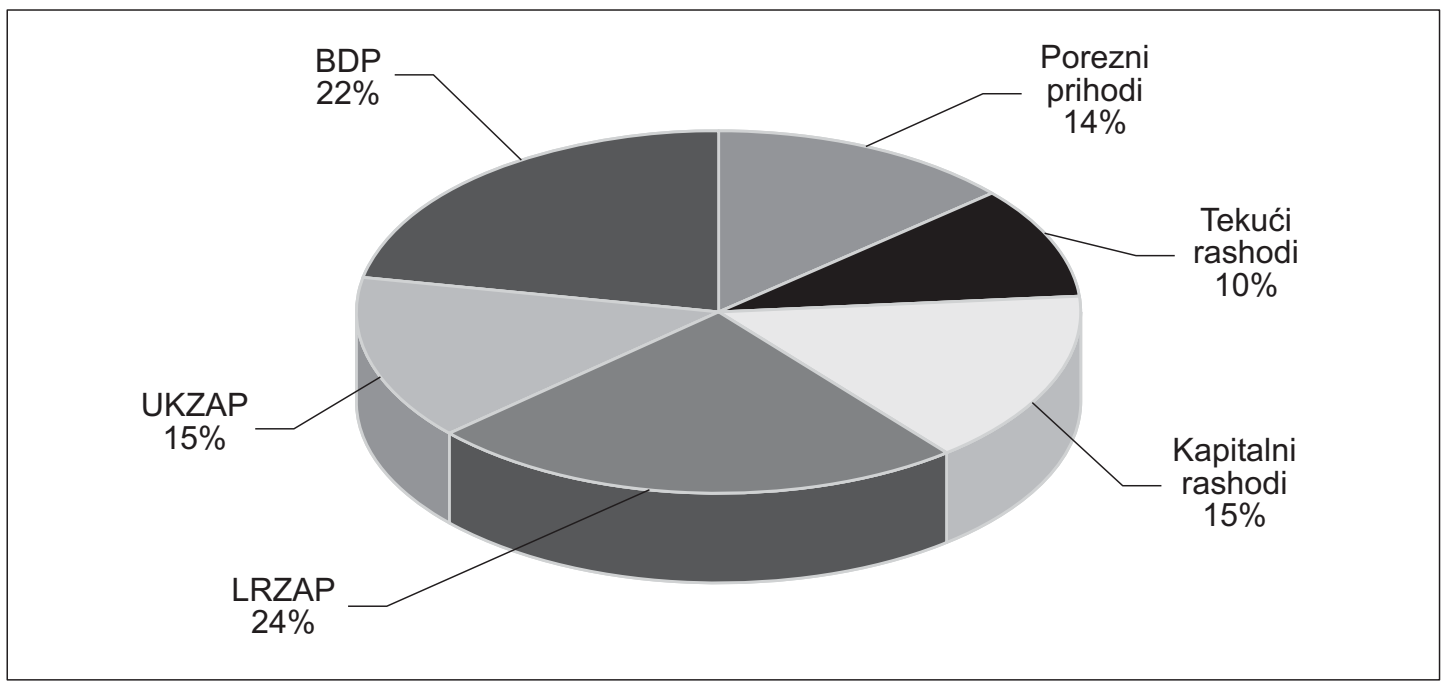

\section{Zaključne napomene}

Usporedna efikasnost 21 hrvatske županije empirijski je ocijenjena na temelju međusobne usporedbe izravnih i neizravnih pokazatelja njihovih fiskalnih performansi, korištenjem analize prozora kao proširenja osnovnog modela metode analize omeđivanja podataka. Analiza je obuhvatila četrnaestogodišnje razdoblje (2002.-2015.), omogućujući tako praćenje dinamike relativne efikasnosti županija. Uporabom dvaju modela, usmjerenih na inpute uz pretpostavku varijabilnog prinosa, koji se međusobno razlikuju u duljinama prozora, performanse županija uspoređene su unutar pojedinih godina i između njih, s fokusom na fiskalnu efikasnost.

Empirijski rezultati sugeriraju nekoliko važnih zaključaka. Prvo, iznosi efikasnosti uprosječeni po županijama tijekom svih četrnaest promatranih godina svjedoče velikim međužupanijskim razlikama. Pritom je Grad Zagreb rangiran kao prvi a Ličko-senjska županija kao posljednja, bez obzira na korišteni model. 
Navedeno ukazuje na empirijsku utemeljenost prihvaćanja prve hipoteze istraživanja: postoje značajne regionalne nejednakosti u Hrvatskoj, pri čemu Grad Zagreb značajno pozitivno odstupa od ostalih županija. Drugo, na temelju veličine neefikasnosti svake županije izvedena je veličina neefikasnosti za hrvatske županije u cjelini, sugerirajući mogućnost povećanja razine efikasnosti. Prosječna bi se ukupna neefikasnost tako mogla smanjiti za $4.1 \%$ odnosno $14.4 \%$, ovisno o izboru modela. Treće, kao opći zaključak, daleko najčešći glavni izvor neefikasnosti jest broj zaposlenih u jedinicama lokalne i područne samouprave, što empirijski potvrđuje drugu hipotezu. Istodobno, tekući su rashodi najčešće najmanje značajan izvor neefikasnosti. Iako tekući rashodi obuhvaćaju i rashode za zaposlene, ovakav zaključak nije proturječan nego ga valja protumačiti na način da su tekući rashodi županija prilično međusobno ujednačeni unatoč prilično neujednačenom broju zaposlenih u njihovim tijelima.

Zaključci ovoga istraživanja, temeljeni na empirijskim usporedbama među županijama, trebali bi biti od interesa analitičarima i pomoći nositeljima politike $u$ Republici Hrvatskoj u prepoznavanju snaga i slabosti njezinog učinka na kretanje razvojnih nejednakosti hrvatskih županija, a time i u oblikovanju ciljane fiskalne politike. Oni daju uvid u razinu i dinamiku relativne efikasnosti i rezultiraju smjernicama za stvaranje novih ili preispitivanje postojećih fiskalnih uvjeta. Kako bi se ovaj uvid učinio cjelovitijim, analiza kroz predložene modele trebala bi se proširiti na dulje razdoblje i uključiti više pokazatelja koji bi odražavali neke dodatne aspekte utjecaja fiskalnog sustava na regionalne disparitete. Tako bi se, primjerice, kao output mogao pridodati prihod poduzetnika po stanovniku, kojim bi se na određeni način provjerila robusnost ovdje dobivenih rezultata.

Premda bi time veći naglasak bio stavljen na BDP, a manji na fiskalne pokazatelje, analizu na temelju ovdje korištenih pokazatelja bilo bi zanimljivo provesti i uz usmjerenje na output, te dobivene rezultate i zaključke usporediti s onima uz usmjerenje na inpute. Kao alternativa do sada korištenim pristupima u domaćim istraživanjima povezanosti fiskalne politike i regionalnog razvoja, u fokusu je ovoga rada neparametarski pristup, no analiza se u nekom budućem istraživanju može provesti na način da se u modele AOMP uključe samo fiskalne varijable $\mathrm{i}$ stopa rasta BDP-a, a da se potom Tobit regresijom analizira učinak početne razine BDP-a po stanovniku, nezaposlenosti i zaposlenosti u lokalnim jedinicama za prosjek svih obuhvaćenih godina. Sve su spomenute mogućnosti otvorene za buduća istraživanja. 
D. RABAR, A. GRBIN: Analiza regionalne efikasnosti u Hrvatskoj korištenjem fiskalnih pokazatelja ... EKONOMSKI PREGLED, 70 (4) 627-649 (2019)

\section{Literatura}

1. Bajo, A. (2009). Struktura zaposlenih u lokalnim jedinicama, Newsletter br. 43, Zagreb: Institut za javne financije. Dostupno na http://web3.ijf.hr/newsletter/43.pdf

2. Bajo, A. i Bronić, M. (2007). Procjene učinkovitosti modela fiskalnog izravnanja u Hrvatskoj. Financijska teorija i praksa, 31(1), 1-24. Dostupno na https://hrcak.srce.hr/12239

3. Banker, R. D., Charnes, A. i Cooper, W. W. (1984). Some Models for Estimating Technical and Scale Inefficiencies in Data Envelopment Analysis. Management Science, 30(9), 1078-1092. Dostupno na https:/www.jstor.org/ stable/pdf/2631725.pdf, https://doi.org/10.1287/mnsc.30.9.1078

4. Bošnjak, K. i Perić, T. (2017). Game theory in the analysis of monetary and fiscal policy on the example of Republic of Croatia. HUMAN, 7(1), 77-82. Dostupno na https://human.ba/wp-content/uploads/2017/04/Full-Issue.pdf\#page=77

5. Charnes, A., Cooper, W. W. i Rhodes, E. (1978). Measuring the Efficiency of Decision Making Units. European Journal of Operational Research, 2(6), 429-444. Dostupno na https://doi.org/10.1016/0377-2217(78)90138-8

6. Cooper, W. W., Seiford, L. M. i Tone, K. (2006). Introduction to Data Envelopment Analysis and Its Uses: With DEA-Solver Software and References. New York: Springer.

7. De Long, J. B. i Summers, L. H. (1991). Equipment investment and economic growth. The Quarterly Journal of Economics, 106(2), 445-502. Dostupno na https://www.jstor.org/stable/pdf/2937944.pdf, https://doi. org/10.2307/2937944

8. Državni zavod za statistiku Republike Hrvatske. (2018a). Bruto domaći proizvod za Republiku Hrvatsku i prema NKPJS-u 2012. - 2. razina i županije. https://www.dzs.hr/Hrv_Eng/Pokazatelji/Bruto\%20domaci\%20proizvod.xls (pristupljeno 13. travnja 2018.)

9. Državni zavod za statistiku Republike Hrvatske. (2018b). Indeks potrošačkih cijena. https://www.dzs.hr/Hrv_Eng/Pokazatelji/MSI\%20CIJENE.xlsx (pristupljeno 13. travnja 2018.)

10. Državni zavod za statistiku Republike Hrvatske. (2018c). Procjena stanovništva prema dobnim skupinama i spolu, po županijama, 31.12. https:// www.dzs.hr/hrv/publication/subjects.htm (pristupljeno 13. travnja 2018.)

11. Državni zavod za statistiku Republike Hrvatske. (2017). Ukupno zaposleni prema administrativnim izvorima, stanje 31. ožujka. https://www.dzs. 
hr/Hrv_Eng/Pokazatelji/ Zaposlenost\%20i\%20place.xlsx (pristupljeno 13. travnja 2018.)

12. Đokić, I., Fröhlich, Z. i Rašić Bakarić, I. (2015). The impact of the economic crisis on regional disparities in Croatia, Cambridge Journal of Regions. Economy and Society, 9(1), 179-195. Dostupno na https://bib.irb.hr/datoteka/792084.cjres.rsv030.full.pdf

13. Farrell, M. J. (1957). The Measurement of Productive Efficiency. The Journal of the Royal Statistical Society, 120(3), 253-290. Dostupno na https:/doi. org/10.2307/2343100

14. Franić, J. (2012). Zapošljavanje na lokalnoj razini u Republici Hrvatskoj tijekom gospodarske krize, Newsletter br. 71, Zagreb: Institut za javne financije. Dostupno na https://doi.org/10.3326/nlh.2013.71

15. Jurlina Alibegović, D. (2013). Less is More: Decentralization in Croatia and Its Impact on Regional Development. U W. Bartlett, S. Maleković i V. Monastiriotis (Ur.), Decentralization and Local Development in South East Europe (str. 51-66). London: Palgrave Macmillan.

16. Kordić, G., Mihelja Žaja, M. i Gardijan, M. (2018). Evaluating fiscal rules efficiency in European Union countries using data envelopment analysis. U A. Mašek Tonković i B. Crnković (Ur.), 7. Međunarodni znanstveni simpozij Gospodarstvo istočne Hrvatske - vizija i razvoj (str. 1014-1022). Osijek: Ekonomski fakultet Sveučilišta Josipa Jurja Strossmayera.

17. Liu, J. S., Lu, L. Y. i Lu, W. M. (2016). Research fronts in data envelopment analysis. Omega, 58, 33-45. Dostupno na https://doi.org/10.1016/j.omega.2015.04.004

18. Mačkić, V. (2014). Political budget cycles at the municipal level in Croatia. Financial theory and practice, 38(1), 1-35. Dostupno na https://doi. org/10.3326/fintp.38.1.1

19. Ministarstvo financija Republike Hrvatske. Financijski izvještaji $J L P(R) S$, razna izdanja. http://www.mfin.hr/hr/financijski-izvjestaji-jlprs (pristupljeno 13. travnja 2018.)

20. Nold Hughes, P. A. i Edwards, M. E. (2000). Leviathan vs. Lilliputian: a data envelopment analysis of government efficiency. Journal of Regional Science, 40(4), 649-669. Dostupno na https://doi.org/10.1111/0022-4146.00192

21. Scott, M. (1991). A New View of Economic Growth: Four Lectures, World Bank Discussion Papers br. 131, Washington, D. C.: The World Bank. Dostupno na https://doi.org/10.1093/ 0198287429.001.0001

22. Šimović, H., Ćorić, T. i Deskar-Škrbić, M. (2014). Mogućnosti i ograničenja fiskalne politike u Hrvatskoj. Ekonomski pregled, 65(6), 541-575. Dostupno na https://hrcak.srce.hr/132919 


\title{
23. Šimović, H. i Deskar-Škrbić, M. (2019). Fiscal Policy and European Semester in Croatia: Why Should We Focus on Public Debt?. U Z. Petak i K. Kotarski (Ur.), Policy-Making at the European Periphery - The Case of Croatia (str. 169-186). Cham: Palgrave Macmillan.
}

\section{ANALYSIS OF THE REGIONAL EFFICIENCY IN CROATIA USING FISCAL INDICATORS - A NONPARAMETRIC APPROACH}

\author{
Summary
}

The uneven economic growth of Croatian counties points to the need for an analysis of their relative efficiency. Among other things, it would be interesting to focus the research on indicators under the dominant influence of fiscal policy. This is exactly the subject of this paper, and the research covers the period from 2002 to 2015 and includes six indicators which are to a greater or lesser extent related to fiscal policy measures. The dynamic analysis is conducted empirically, using the nonparametric method of data envelopment analysis (DEA), at the county level at which are also given the guidelines for necessary improvements, which is novel in comparison to previous literature. The obtained results of 21 counties' efficiency confirmed the hypothesis of significant inter-county disparities and the leading position of the City of Zagreb in the sense of selected indicators, also pointing to inefficiency sources among which the most prominent is the number of employees of local and regional self-government units. The results should serve the economic policy makers in the efforts to improve fiscal decisions with the aim of reducing regional differences.

Keywords: fiscal indicators, economic growth, (in)efficiency, Croatian counties, data envelopment analysis, window analysis 